\title{
Being Ritual in Mesolithic Britain and Ireland: Identifying Ritual Behaviour Within an Ephemeral Material Record
}

\author{
Edward Blinkhorn ${ }^{1} \cdot$ Aimée Little ${ }^{2}$
}

Published online: 17 July 2018

(c) The Author(s) 2018

\begin{abstract}
Acceptance of ritual as a valid interpretation of Mesolithic behaviour has slowly emerged over the past decade; the 'silly season' heralded by Mellars (Antiquity $83: 502-517,2009$ ) has not materialised, though in Ireland and Britain difficulties persist in defining what might constitute 'ritual' away from the graveside. New discoveries from both the development-led and academic sectors enable Mesolithic archaeologists to better establish which elements of the archaeological record can be interpreted as ritual. This paper seeks to identify further strands of ritual behaviour, incorporating evidence from sites without organic remains. We consider the evidence for ritual at the site and feature scales, and in the special treatment of objects - an often overlooked body of data in understanding ritual. Thus the material signature of ritual will be questioned, and ways in which Mesolithic ritual can be rehabilitated and expanded will be explored.
\end{abstract}

Keywords Ritual · Mesolithic $\cdot$ Britain $\cdot$ Ireland $\cdot$ Mundane

\section{Introduction}

Willingness to accept ritual in Mesolithic narratives seems to have increased in recent times. However, there is still a sense that we are waiting for some other inherently ritual piece of evidence to emerge; one that will satisfactorily bridge the gap between Upper Palaeolithic burials and artwork, and the ritual landscapes of the Neolithic. It is important to state from the outset that the purpose of this paper is not to review the impact of Chatterton's original 2006 paper titled 'Ritual', a comprehensive study of archaeological evidence for ritual behaviour in Mesolithic Britain

Edward Blinkhorn

e.blinkhorn@ucl.ac.uk

1 Institute of Archaeology, University College London, 31-34 Gordon Square, London WC1H 0PY, UK

2 BioArCh, Department of Archaeology, University of York, Environment Building, Wentworth Way, York YO10 5DD, UK 
and Ireland, nor review the evidence implicated within. Rather, as well as discussing the many discoveries made since Chatterton's publication, we place new emphasis on the potential contribution of seemingly mundane-and less mundane-acts of ritual discernible from the archaeological record of Ireland and Britain (see Fig. 1 for the location of all sites discussed).

We have chosen to focus on the mundane not out of necessity-the archaeological record is not as impoverished as we often lead ourselves to believe, even if we are missing the stand-out ritual sites of Scandinavia (Hallgren and Fornander 2016) - but because it is mundane acts which make up our more ephemeral material record, and it is those acts which best capture the multitude of everyday cultural expressions of ritual activity in this part of Europe. By interconnecting ritual with the mundane, this paper aims to provide a methodological and theoretical framework around which Mesolithic ritual can be better articulated.

The decade since the publication of Chatterton's Ritual chapter (2006) has witnessed a large number of new Mesolithic discoveries in Ireland and Britain, not least due to the impact of developer-led projects. Despite the emergence of new data, and for various reasons (e.g. time/money), commercial output tends towards integrating evidence within the academic status quo, which for the Mesolithic often involves reiterating older narratives of the economics of hunting and, to a lesser degree, gathering. As such, the full potential of these discoveries as reference points for the role of ritual in everyday life during the Mesolithic has yet to be realised. Similarly, it became apparent during the course of this research that, with limited exceptions, few academic-led projects from Ireland or Britain have sought evidence for ritual, save work at Star Carr (Little et al. 2016; Milner et al. 2016; Taylor et al. 2018), itself a well-established place of ritual arguments.

In the absence of a proper synthetic framework, interpreting ritual within the Irish and British Mesolithic is perhaps a poisoned chalice. Yet in our exploration of the more mundane aspects of ritual, we found a rich and often untapped empirical dataset from this part of Europe. At times the connections we make between material remains and ritual behaviour complement ideas raised previously by Chatterton. We extend his theoretical discourse by sparking new interpretative associations between people, things, places, and concepts of ritual within the archaeological record. In following Chatterton's chapter, and to reassert a rejection of a ritual/functional dualism, we in part borrow the thematic structure he used.

\section{Recent Perspectives on Mesolithic Ritual in Ireland and Britain}

Chatterton's (2006) chapter stands in limited company as a synthetic review of the Irish and British Mesolithic. As well as providing a synthesis of ritual activity, he attempts to highlight geographical and temporal variation across the Mesolithic from both Britain and Ireland, and notes that there has been 'no systematic analysis of ritual activity' in the Mesolithic period in this part of Europe (Chatterton 2006, p. 101). Informed by various authors, and rejecting a dualistic approach, Chatterton emphasises the ritual aspect of an action, rather than a kind 


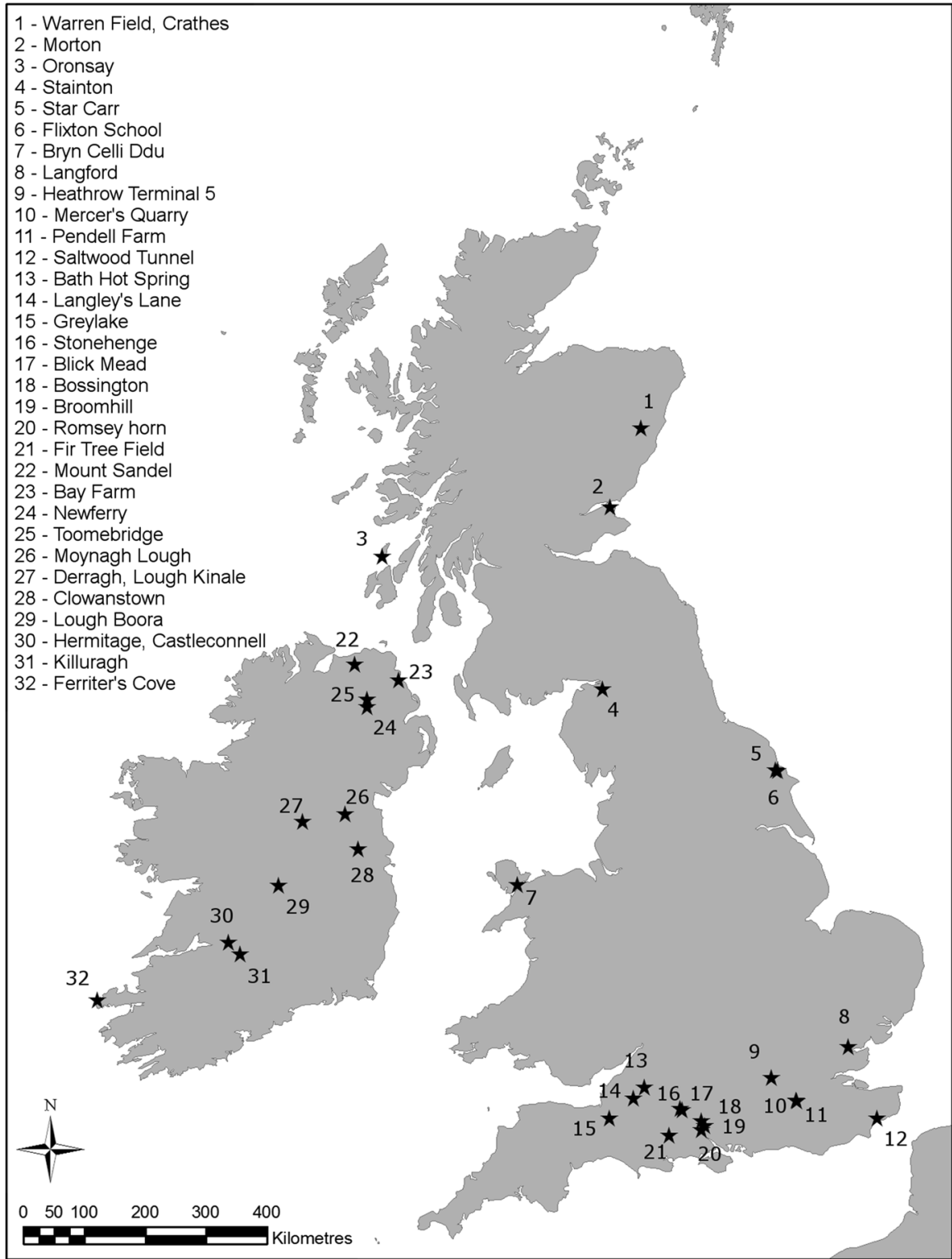

Fig. 1 The location of Mesolithic sites in Ireland and Britain discussed in text

of action that is ritual, allowing actions to perform multiple roles. This is principally framed in his paper in terms of depositional actions at a selection of sites; nonetheless, it is a useful précis of what ritual is, or can be.

Conneller (2011) draws on a number of themes deriving from mortuary questions and perspectives developed from ethnography. She identifies as pertinent rites 
of passage, sacred places, the importance of animals, the three-tiered world and the role of the shaman as religious specialist, interceding with (animal) spirits. The degree to which events and relationships between different people, animals, things, and places need be mediated by non-shamans is not addressed, perhaps rendering Conneller's ritual 'special'.

In the Scottish Archaeological Research Framework, in part shaped by Warren, further elements of the ritual spectrum are recognised, comprising the importance of distinctive landscape features, seasonal events, attitudes towards discard and depositional practices, and the treatment of the dead' (ScARF 2012). Places and deposition again figure, but a temporal framework is added, in some respects akin to rites of passage. Treatment of the human dead of course is central, but not really within the scope of this paper, although the special treatment of objects and places as 'dead' certainly demands consideration (Little et al. 2017).

Even Mellars, in his broadside on post-processual approaches to the remains at Star Carr, has conceded that emphasis on "both the social/historical/ideological dimensions of [Star Carr] and the crucial environmental, ecological and economic aspects of the occupation is ... indispensable if we are ever to achieve a balanced evaluation of Star Carr in the overall social context of the British Mesolithic' (Mellars 2009, p. 516).

Popular use of the word ritual as a junk category for the inexplicable has unfortunately rendered it akin to weird or magical, and distanced it from the simple reference to established rites and their observation (OED 2018). This muddied understanding of the term has set ritual approaches in opposition to those considered to be evidence-based, that is, explanatory and data-led, rather than integral to interpretations.

Academics still fall into distinct camps: science or theory, with ritual very rarely being discussed with the benefit of modern advances in archaeological science. Again, this division between cultural archaeology and the fast growing field of archaeological science is a mindset particularly ingrained in Mesolithic studies, with Ireland and Britain being no exception. Similarly, commercial archaeology references locally and nationally significant literature, itself rarely synthesising Mesolithic remains which are most often overshadowed by later, more extensive (and expensive), deposits. While acceptance of an intangible ritual undercurrent has become more accepted, understanding of what this ritual might be has not developed significantly.

It is with this history of research in mind that we set out to explore the more mundane aspects of ritual within the Irish and British archaeological record. We outline a framework for thinking through the data, its context and meaning. To do this we use the concept of a three-tier universe to create a schema through which past material cultural practices can be better contextualised, though in doing so we also recognise potentially more diverse cosmological approaches. By no means do we claim that our approach is a universal given, nor do we suggest a direct historical link between modern and past hunter-gatherer communities. What this approach does allow, however, is a preliminary categorisation of behaviour by which the evidence can be interrogated and compared. 


\section{Ritual Themes}

\section{Tidying Up: The Surface}

The character of deposition in the Mesolithic has been given limited attention within the history of research, especially as regards understanding the social structuring of space, although in Ireland and Britain examples can be found where spatial patterning in deposits has illuminated a sense of both ritual and routine.

Division of space into 'clean' and 'unclean' areas is known from ethnographic research on the landscapes of the Khanty, Western Siberia (Jordan 2003a, b), as is the segregation and maintenance of ritual sites through the practice of (mostly repeated) deposition of seemingly refuse-like items, such as bones of various animals, alongside meat, fish oil, and in later times, alcohol at Sámi Sieidi sites. In a Mesolithic context, 'thoughtful discard practices' (Conneller and Schadla-Hall 2003, p. 100) were identified around Lake Flixton in the Vale of Pickering, Yorkshire, where tool-making activity sites were said to be isolated from knapping stations and are either located at the water's edge, or in the water itself. In this case evidence pointed to people deeming it appropriate to 'undertake particular tasks away from the knapping stations or on longer lasting activity areas on the drier ground' (Conneller and Schadla-Hall 2003, p. 100).

In Ireland, re-interment of 'waste' into hearths appears a common theme. At Ferriter's Cove, spatial patterns in the distribution of material suggested food was 'carried to other parts of the site and dumped as refuse' (Woodman et al. 1999, p. 126). At Lough Boora (Ryan 1980), heavily calcined bone fragments were interpreted as having been exposed to prolonged burning after the meat was removed, indicating that this was 'not part of the normal food preparation procedure'-instead, it appeared they 'were deliberately discarded into the fire' (Van Wijngaarden-Bakker 1989, p. 126). If the evidence from across Britain were similarly interrogated, this might emerge as a recurrent pattern amongst a common evidence class.

In the aforementioned examples, evidence of economic and subsistence-related activity could be assumed from the data, yet all are suggestive of more ritualised and structured acts of deposition as well. This is not to say that subsistence and ritual are divorced from each other. Indeed, as Brück (1999) has noted, it is more likely that ritual was an integral part of daily life and subsistence practices, involving a necessary reciprocal arrangement between people and nature that ensured future livelihood. Thinking in this way, it may not be entirely far-fetched to conceive of the Early Mesolithic pit at Hermitage (containing cremated human bone deposits, a polished stone axe, and fragmented burnt stones, and with no evidence of burning of the pit edges) as not unusual or ritualised in the non-rational sense (see Brück 1999), but rather, a continuation of everyday routines which regularly involved careful placement of bones, stones and organic materials.

Graeme Warren's critique of accepting middens as monuments (2007), themselves expressions of tidiness, was a necessary articulation of the frustrations generated by importing Neolithic- or even GIS-driven conceptions of ritual space and action. Asking us to pick apart the components of the midden to argue for the 
significance of a monument, Warren's point can easily be extrapolated through other classes of Mesolithic deposit.

\section{Monumentality}

The evidence that cremation as a mortuary rite was practised in both Ireland (Collins 2009) and Britain (at Langford in Essex: Gilmour and Loe 2015) from as early as 7530 cal. BC and as late as 5600 cal. BC respectively, suggests that mortuary rituals accompanying cremation were temporally and spatially expansive. A post pipe in the base of the Pit A burial at Hermitage has been interpreted as evidence of a grave marker, implying a constructed burial memorial (Fig. 2). It also suggests that the ritual act of commemorating the dead was practised not just once at the graveside but repeatedly through time: requiring a physical (in this case, artificial) landmark, or even, 'totem' (Little et al. 2017). The totem perhaps then physically and symbolically linked the three-tiered system, the upper tier being the sky/heavens/upper-other-world; the lower tier the subterranean/submarine/lower-other-world; and the middle tier a world populated by observable phenomena. As discussed below, as well as in recent interpretations of the motif on the Star Carr engraved pendant (Milner et al. 2016), the tree of life is well recognised within hunter-gatherer shamanic and religious worldviews. The wooden post used to mark the grave at Hermitage could be considered analogous to the tree of life, allowing safe passage for the deceased on their journey to other worlds.

Leaving aside the grave post, the Irish Hermitage cremations (burial pits A, B and $\mathrm{C}$ ) were different in their composition, and span more than a thousand years, suggesting that the location itself - a fording point—was significant, whether or not it was artificially marked. The repeated use of a cave, as at Killuragh, County Limerick, to dispose of the dead (Meiklejohn and Woodman 2012) may be part of the same memorialising tradition, with the cave environment providing a structural analogy for upper, middle and lower worlds of being.

Burial sites in the Irish and British Mesolithic are, however, rare. More common is the enhancement of natural features. In fact, we go as far as to suggest that this is a shared and common theme for both Ireland and Britain, and merits further exploration.

Natural islands adjacent to major water bodies were deliberately chosen for augmentation through a process of structured deposition, most probably over the course of subsequent occupations. A natural island was built upon, using mostly stone, but also layers of brushwood and peat at Derragh, Lough Kinale (Fig. 3a, b) (Fredengren 2009, p. 884). At Clowanstown, the construction materials took another form: burnt timbers were used to consolidate a 'natural platform' (Mossop 2009). Further east at Moynagh Lough, hunter-gatherers artificially enhanced two knolls with stones and white lacustrine mud, which would have provided dry areas of ground within the original lake (Bradley 1991, p. 7). John Bradley describes the deposits at Moynagh Lough as appearing to have been 'thrown down' (Bradley 1991, p. 9), suggesting a rather ad hoc conception and construction of the platform. He further 


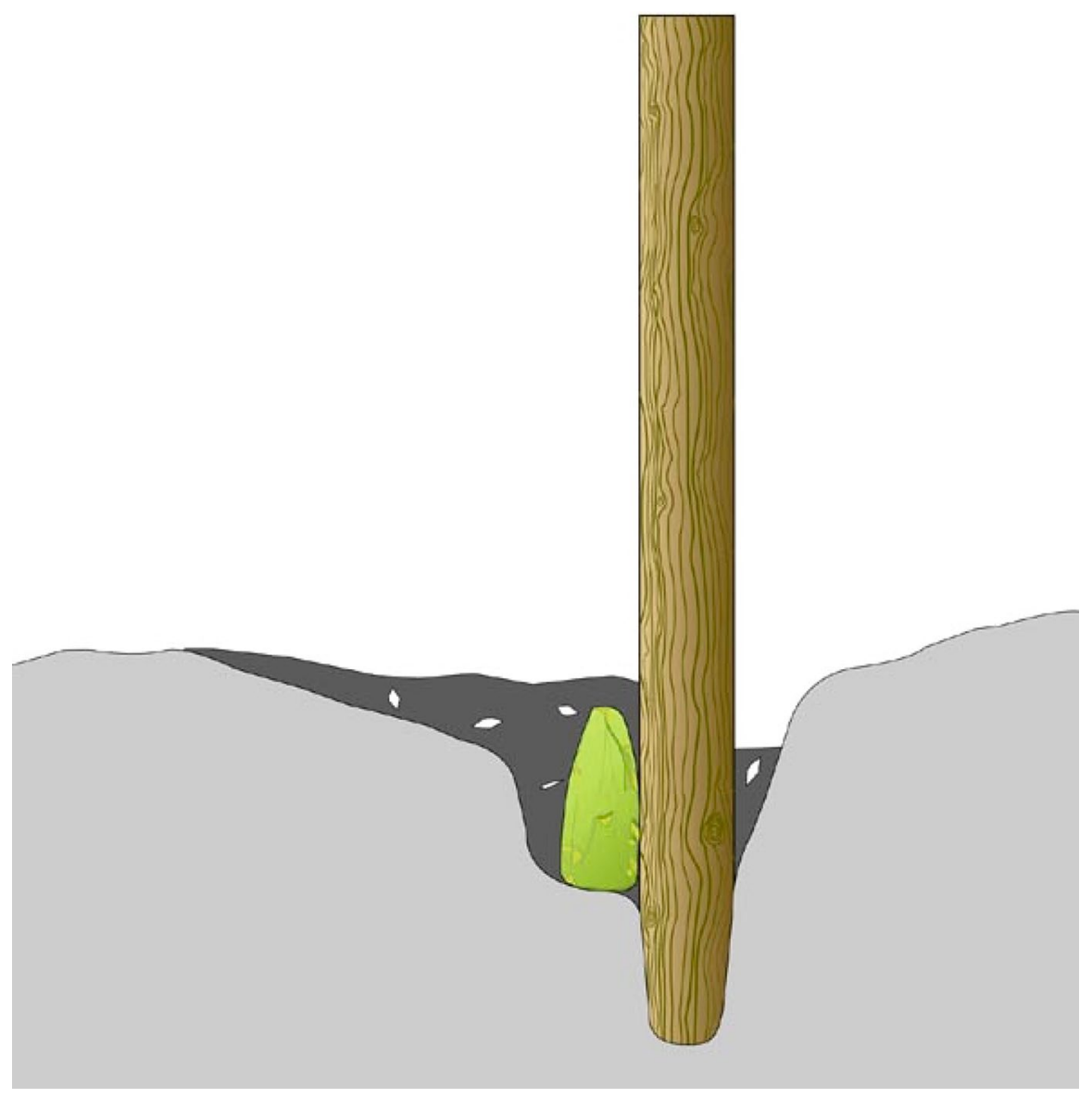

Fig. 2 Reconstruction of the Hermitage Pit A Burial with axe, cremation deposit and a wooden post grave marker. Credit: Tracy Collins, Aegis Archaeology Ltd.

points out (somewhat contradictorily) that this redeposited mud was 'almost completely sterile and its presence is difficult to explain' (Bradley 1991, p. 9).

The tradition of platform construction at sites like Star Carr (Bamforth et al. 2018), and the enhancement, stabilisation and (in some cases) artificial extension of the edges of natural knolls at Irish Midland sites, best exemplify the spatial relationship hunter-gatherers had with the transitional zone between the wet and the dry (Little 2010).

The Oronsay shell middens-again, large white and mound-like in form-provide another example of highly visible constructions within the Mesolithic landscape, of which Finlay has written, 'at one level such entities are permanent markers of the impermanence of daily tasks, but also liminal entities located between the land and sea' (Finlay 2004, p. 4). As with the other examples provided here, platforms and accumulations of activity in Ireland and Britain share a similar spatial 


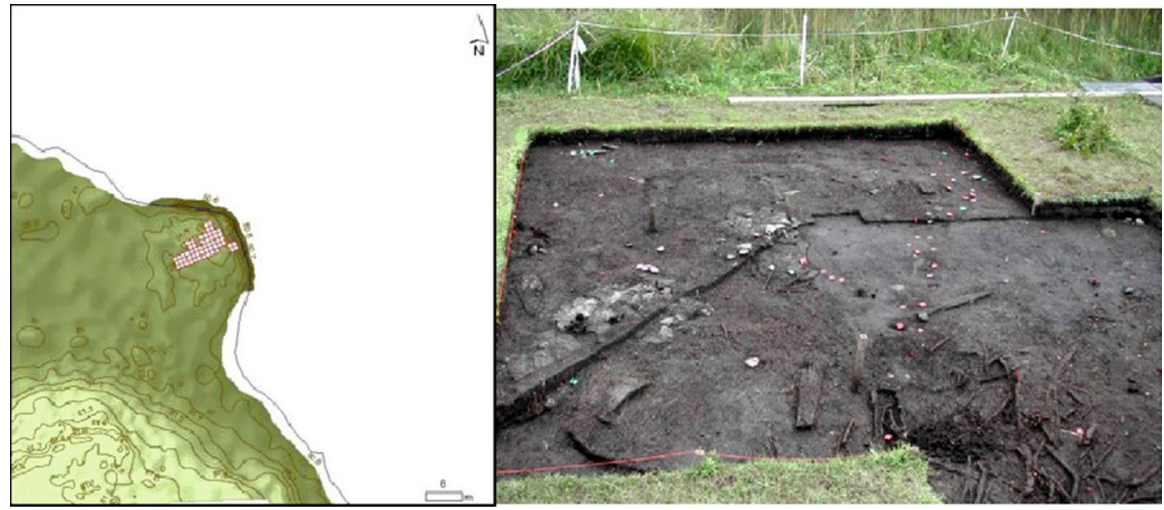

Fig. 3 Topographical survey showing the location of the Derragh, Lough Kinale platform (left); a photo of the platform mid excavation (after Fredengren 2009) (right)

theme whereby the transitional zone between wetland and dryland-a dynamic and changing environment of flux and flow-is physically and temporally fixed via a process of repeated activity (Little 2005).

But are augmented islands, platforms and middens monuments? We propose that rather than seeking to identify acts of monumentality, it is more productive to engage with the specifics of the material and develop frameworks that 'bridge the gap between creative interpretations and the prehistoric material evidence' (Jordan 2003 c, p. 130). The fact that hunter-gatherers were physically modifying their environment by constructing platforms and enhancing islands, when traditionally 'the hunter-gatherer (almost by definition) may be supposed to inhabit a natural rather than an artificial environment' (Ingold 1996, p. 187) seems a much more useful starting point for initiating a discussion of the ways in which people in the Mesolithic set about transforming the landscape (Driscoll 2006).

\section{Watery Places}

A ritual significance of watery places in the Mesolithic has been bolstered by new discoveries. At Bath Hot Spring, Brooks (2007) argues that the c. 500-strong heattreated lithics assemblage recovered from the spring pipe did not fit a traditional economic model and guardedly interpreted the assemblage as Early Mesolithic ritual deposition. At the only true hot spring system in the British Isles, the constant $46{ }^{\circ} \mathrm{C}$ water temperature would have supported a distinct local flora, creating an equally distinctive ritual space.

Excavations at Langley's Lane near Midsomer Norton, Somerset, by Davies and Lewis (2005) have identified a series of pits at the edge of a tufa deposit and associated with Late Mesolithic lithics and faunal remains. Finds in the pits of lithics, fossils and a seemingly formed tufa ball led the authors to suggest, albeit hesitantly, that there is a votive aspect to the site. 
A dating program on skulls from Greylake in Somerset (Brunning and Firth 2012) has potentially afforded England's first open-air cemetery. Whether focus on island archaeology — such as on the islands of the Thames at the start of the Holocene-might extend the better-accepted rituals of the graveside into more mundane environments remains to be seen.

An emphasis on watery places could be argued to be a product of enhanced preservation conditions. The majority of Mesolithic sites are open-air, and most often only marginally associated with water sources. Mesolithic deposits which have been sealed by alluvium or preserved by other means such as peat development are likely to be more intact, thus revealing deposition practice in more detail, but equally biasing narratives of 'everyday' and 'special' practice. However, we might question why it was deemed necessary to extend living spaces out into the shallows, effectively bridging land and water. The functional interpretation applied to sites like Moynagh or Derragh, Lough Kinale in the Irish Midlands, is that this was an economic adaptation, providing a better fishing spot. However, there are easier ways to catch a fish than to build a platform or augment an island, especially given the evidence we have for watercraft at this time (Woodman 2015). It is here that we return to the concept that fluctuating environments such as the examples provided above, may have been perceived as extraordinary places - their marginality providing a centre for ritual expression. These were the places perhaps deemed most suitable for the performance of rituals of negotiation between the three-tiered universe where the ability to transcend states of matter was key.

\section{Structures}

With difficulties in articulating Mesolithic patterns of mobility, the temptation is to settle hunter-gatherers in dwellings when the opportunity arises, perhaps on the supposition that the evidence implicitly suggests the fulfilment of a basic human requirement. Following the discoveries at Mount Sandel (Woodman 1985) and Broomhill (O'Malley and Jacobi 1978), a raft of new structures have been found across the British Isles, for instance, at Star Carr (Fig. 4) (Taylor et al. 2018). The instinctive domestication of the structure as a dwelling is understandable, but does not satisfy aspects of the formalities of its location, construction, use and disuse. The home may have more identities than a dwelling.

Evidence from ethnography for nomadic structures illustrates a richer side to building: yurts represent the universe in microcosm and, less famously, tents of Nganasan and Nentsy (Nenets) shamans incorporate a modified birch tree, representing the soul of the clan and aiding the occupant's travels between upper, middle and lower worlds (Faegre 1979). Adrian Tanner's classic study (1979) demonstrated how Mistassini Cree spatial organisation of life in camp can reflect social and ideological organisation, whilst Plains Cree lodge construction has been described as undertaken with 'a great deal of prescribed ritual' (Mandelbaum 1979). Dwellings are instrumental in the Selk'nam Hain rites, in construction, orientation, and position (Chapman 2003). Whilst these buildings may in some cases substantively form 


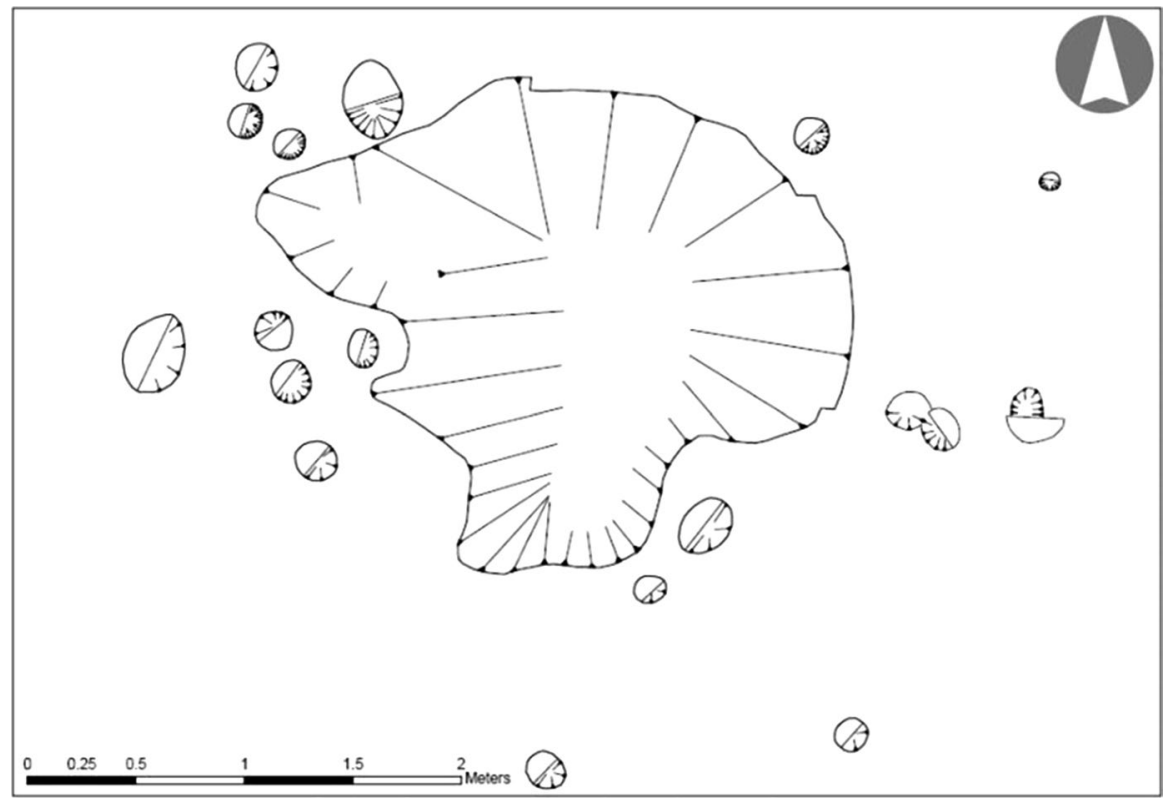

Fig. 4 Star Carr circular house structure in plan view. Credit: Star Carr Project

dwellings, at least at certain times, location, construction, structural elements and use make up entities that are more than simple shelters.

What is most striking is recurrence in the form of the more substantial Mesolithic structures. Although plenty of different materials and forms are viable, the round structure incorporating supporting posts has enduring currency. The internal logic of building construction may be readable therefore even if the meanings are lost, and common features of construction might share common mechanical and ritual properties. The Irish structure excavated at Toombridge (Dunlop 2010), however, appears to have suffered a ritual interpretation owing to a lack of domestic evidence or familiar form.

Whilst a building may represent a formal constructed organisation of ritualised space, the maintenance of the landscape argued for the British Isles may preserve a logic for the organisation of ritualised 'natural' space, accessible through palaeoenvironmental analyses. Newell's (1981) critique of 'pit-dwellings' excavated in the first half of the twentieth century recapitulated a nature-culture dichotomy, implicitly treating natural tree-throws (holes left by uprooted trees) as 'less important' evidence than humanly-constructed dwellings; this judgement needs revisiting.

\section{Pits}

Evidence for Mesolithic pits has rapidly expanded in the past two decades: Blinkhorn (2012) and Lawton-Matthews (2012) have documented significant numbers for England and Ireland respectively, indicating that pits are a common 
phenomenon. While Chatterton prioritised deposition, it was Allen and Gardiner (2002) who, in their treatment of Mesolithic pits as 'cultural markers', reinstated their interpretive potential and, by considering 'empty' pits as landscape features, lent aspects of activity to pits additional to a pedestrian interpretation as containers for 'things'.

Other established interpretations for pit activity are characteristically containerbased, including: marked interments (Collins 2009); roasting pits (Mithen 2000); storage (Woodman 1985); midden disposal and deliberate lithics deposition (Chatterton 2006); and raw material procurement (Clark and Rankine 1939), though others also exist. Those with few or no associated finds remain even more obscure in meaning, though the pine charcoal from the pits at Stonehenge (Cleal et al. 1995), Warren Field (Murray et al. 2009), and Bryn Celli Ddu (Burrow 2010) allow comparisons to be drawn across Mesolithic Britain. Variety in pit usage has been established by academic projects, yet pits feature infrequently in narratives of ritual unless they are found to be extraordinary in some respect. The unequivocally Mesolithic, and extraordinary, pit alignment at Warren Field, Aberdeenshire (Murray et al. 2009), has been argued to have astronomical associations as a 'time reckoner' (Gaffney et al. 2013), reflecting and marking an important landscape position, and possibly associated with crushed coloured minerals from geological sources nearby. The Heathrow Terminal 5 pit group was found alongside a palaeochannel and was filled with burnt flint, and within the ditches of the Neolithic Stanwell cursus (Lewis et al. 2010). Both sites invite consideration of upcast as materially important, although it was the contents which led to divergent ritual or economic interpretations.

Tidying up can be seen in those instances where pits contain lithics, especially those where the lithics are considered to have been placed. Examples from Mercers Quarry (Hammond 2005) and Pendell Farm (Lewis and Pine 2008), both in Surrey, contain narrow-blade assemblages with high percentages of spall lending credence to their interpretation as disposal from a knapping event. Irish examples have been classified as caches dependent on debitage ratios, but Pit F1 at Bay Farm compares well with the English evidence.

Other placed deposits are more conspicuous. Most intriguing are the eight Horsham microliths recovered from a small, shallow pit discovered at Saltwood Tunnel (McKinley et al. 2006). The uniformity of form and distribution potentially indicates deposition as a composite tool, or in a bag, and the broken tips of several of the tools are suggestive of damage through use-things which might be verified by use-wear analysis. Aspects of this deposition hint at more than the casual discard of a utilised tool. The Fir Tree Field shaft (Green 2000) similarly contained a group of (rod) microliths, and although they cannot confidently be called 'placed', the association with animal remains inevitably invokes a hunting scenario, despite geoarchaeological work revealing anthropogenic clearance around the feature contemporaneous with the microliths.

Mesolithic pit use in most cases seems to reveal not so much grand expressions of cosmology as glimpses of 'correct' treatment. Objects are placed to remove them from the observable world, and the pits-natural or anthropogenic, filled or 
unfilled-are recognisable landscape features with meaning. In some instances, where these features persisted, they may be referenced by later activity.

\section{Art and Things}

While we are now fairly comfortable with the idea that in the Irish and British Mesolithic bodies received special treatment (Conneller 2006), a lack of literature on the subject would suggest we struggle to embrace the idea that objects did too. Where in the Neolithic researchers use microscopic techniques and experimental research to explore the biographies of tools and their social as well as ritual role within society (van Gijn 2010), we are yet to see anything comparable attempted for stone tools and other materials/classes of objects from the Irish and British Mesolithic. As such, there remains a massive gap in our understanding of the role things played in Mesolithic ritual life.

We know that some objects were probably used in rituals a) and thus by proxy became 'ritual objects'. Additionally, objects themselves were subjected to ritual treatment and processes (see Little et al. 2017). Caching is a well-known aspect of the Irish Late Mesolithic material record (Finlay 2003; Woodman 2015, pp. 140-143), though what do we really know about the life history of objects that were collectively concealed in various parts of the landscape, sometimes in water? In Ireland, Finlay (2003) has noted that objects in caches often appear in groups of three (perhaps symbolic of the three-tiered cosmology?), whilst Woodman uses the curiously arranged cache of six blades from Newferry (cache 1) to reflect on whether 'ritual' and 'caching' should be considered mutually exclusive (Woodman 2015, p. 143). This last example from Newferry is striking in that, as with the Hermitage axe, vertical placement of the objects into the earth suggests not just intentionality, but a form of material syntax, codifying the three-tiered universe.

An integrated technological/use-wear/residue study of objects classed as 'cache' would be a good starting point in addressing some of these questions. At the most basic level it would provide an overview of what types of objects re-occur in cache contexts across Ireland and Britain, and whether they are being placed in the ground used or unused. Macro and microscopic examinations, alongside experimental research, could be used to investigate evidence for burning, breakages and other forms of (deliberate) damage, as well as the application of substances such as ochre, sometimes only visible microscopically. In short, we need to start employing a broader range of scientific and visual imaging techniques to really explore the biographies of enigmatic depositions, including cached objects, such as those analysed for wear traces from Star Carr that revealed evidence for more than raw material provisioning (Conneller et al. 2018).

Mesolithic cave archaeology has not been particularly active in recent years, though contenders for parietal artwork have emerged. Less controversial are mobiliary examples, including the antler tine from Romsey, incised with chevrons recovered during the construction of a water treatment works in the 1930s, now radiocarbon dated to the Early Mesolithic (Elliott 2012). Most recently, the discovery of a pendant at Star Carr (Milner et al. 2016; Needham et al. 2018) has reasserted a 
Mesolithic capacity for symbolic expression, in this instance through engraved artwork which has been suggested to represent a possible shamanic totem.

\section{Colour}

Visual portrayals of the Mesolithic tend to represent a verdant landscape on which people undertake tasks, assembling a compendium of archaeological interpretive standards to convey a lost way of being. However, tufaceous and shell midden sites would introduce a broader palette to these images; colour may have been a significant detail for hunter-gatherers.

The colour white can be derived from various sources, including subaquatic ones (molluscs and springs), chalk exposures, and calcined organic material. Additionally, normally dark flints are turned white through recortication and burning. Algae at Blick Mead spring, from where sizeable lithics and faunal assemblages have been recovered, is known to turn submerged items pink (Jacques and Phillips 2014), drawing together the potential ritual aspects of colour, transformations in state, and watery places. The Hot Spring, Bath, could equally be considered an apposite depositional choice for the associated heat-treated lithics with, in this instance, heat providing the transformational force. Perhaps, too, the use of tufa, a mouldable solid, had ritual connotations due to its natural fluctuating state.

Tufaceous sites such as Bossington (Davies and Griffiths 2005), Moynagh Lough (Bradley 1991) and others discussed by Davis (2012) will have stood out as landscape anomalies. Tufa forms a geoarchaeological context for preservation, but may also be treated as a material (as in the Langley's Lane tufa ball) or spiritual resource. The creation of an artificial 'white island' like that at Moynagh could be interpreted in a variety of ways. From a functional perspective, these marls may have been used to create a level living surface, raising the knolls above the water level. Yet it is not difficult to imagine that this 'white island' would have had a profound visible impact on those approaching by boat (Little 2005, p. 91). Davis (2012) did not find a lithic ritual signature at spring sites in southwest England, nor evidence for distinct ritual landscapes, instead favouring an argument of the sacred and profane spatially coexisting. Considering the strong association with white tufa deposits emerging from Britain, it is not unfeasible that the application of marl deposits to the natural island at Moynagh was part of a geographically broad ritual tradition.

Evidence from Ireland and Britain does not record red ochre as a feature of funerary rituals. Nevertheless, microwear analyses on the broken edges of later agricultural implements from the continent have identified the application of ochre, perhaps demarcating objects as special or dangerous (van Gijn 2010). As microscopic analysis has yet to be extensively used on Irish or British Mesolithic assemblages, it is difficult to determine if this or similar practices were in use. However, finds of ochre 'pencils' or incised lumps from Morton (Coles 1971), Stainton (Brown 2011), Flixton School (Needham et al. 2018) and others imply some undetermined use.

Although the meanings of different colours are uninterpretable, understanding the suite of archaeological contexts where they are found can be helpful in approaching 
a structured argument, as could an understanding of how colour was made and applied to people, things, and places (Walker 2015).

\section{Discussion and Conclusions}

Glimpses of ritual life in Mesolithic Ireland and Britain are offered by a suite of different finds, features, deposits, and landscapes. However, it is difficult to extrapolate coherent explanations or interpretations which build on the evidence and which point to an inherent or implicit structure, not least because our evidence is geographically diverse and covers 5500 years. We should also consider that evidence for ritual within the material record of Ireland and Britain is often more ephemeral/discrete than in other parts of Europe, requiring more intensive investigation, but possibly giving rise to more nuanced interpretation and discussion. Furthermore, if some actions are to be categorised as more 'common' or more 'special', then the evidence must be organised in a manner that encompasses the full ritual spectrum and allows for scalar changes in the interpreted 'specialness' of deposits.

If commonalities with other northern latitude hunter-gatherers identified by Conneller (2011) and Zvelebil (2008) are accepted, a three-tier cosmology may be helpful in marshalling the evidence. Using this scheme, we identify the upper tier as the sky/heavens/upper-other-world; the lower tier as the subterranean/submarine/ lower-other-world; and the middle tier as a world populated by observable phenomena/people/animals/unobservable phenomena. The evidence, in turn, can broadly be classified incorporating a range of discoveries from the unique, to the diverse and common. In Fig. 5, one possible simplified organisation of this evidence is presented, using a three-tiered cosmology as a framework.

If rituals are taken as mediating actions, on whatever scale, then they are articulated in Fig. 5 as mediations between these worlds. There is no reason to expect evidence on the scale of Neolithic monumentality and the cooperative industriousness it entails. Ritual in hunter-gatherer societies entails doing things right, therefore a smaller scale of repeated or extraordinary events must be sought if we are to uncover a ritual component to Mesolithic life. Furthermore, if, as we are often besought to believe, a way of life further from Western dualistic categorisations is to be posited for Mesolithic people, then perhaps these rituals should be sought within the everyday (mundane) acts of living, being neither exclusively ritual, nor exclusively economic.

Water in different manifestations can be a place of deposition, and an instigating factor in movement and changes of state. Even in death, animals and other resources are treated correctly and 'tidied'. Shelters, or structures, are yet to be anything more than presumed to be dwellings; we suggest that other aspects of their use should be considered. A consideration of colour extends ritual beyond the material, while pits offer valuable empirical data; neither form of evidence has been fully utilised in discussions of ritual behaviour in Mesolithic Ireland and Britain. We have argued that conceiving of platforms and augmented islands as monuments diminishes their specialness and does not account for the broader Mesolithic context of behavioural evidence within which they are best interpreted. Instead, we argued that these constructions represent a 


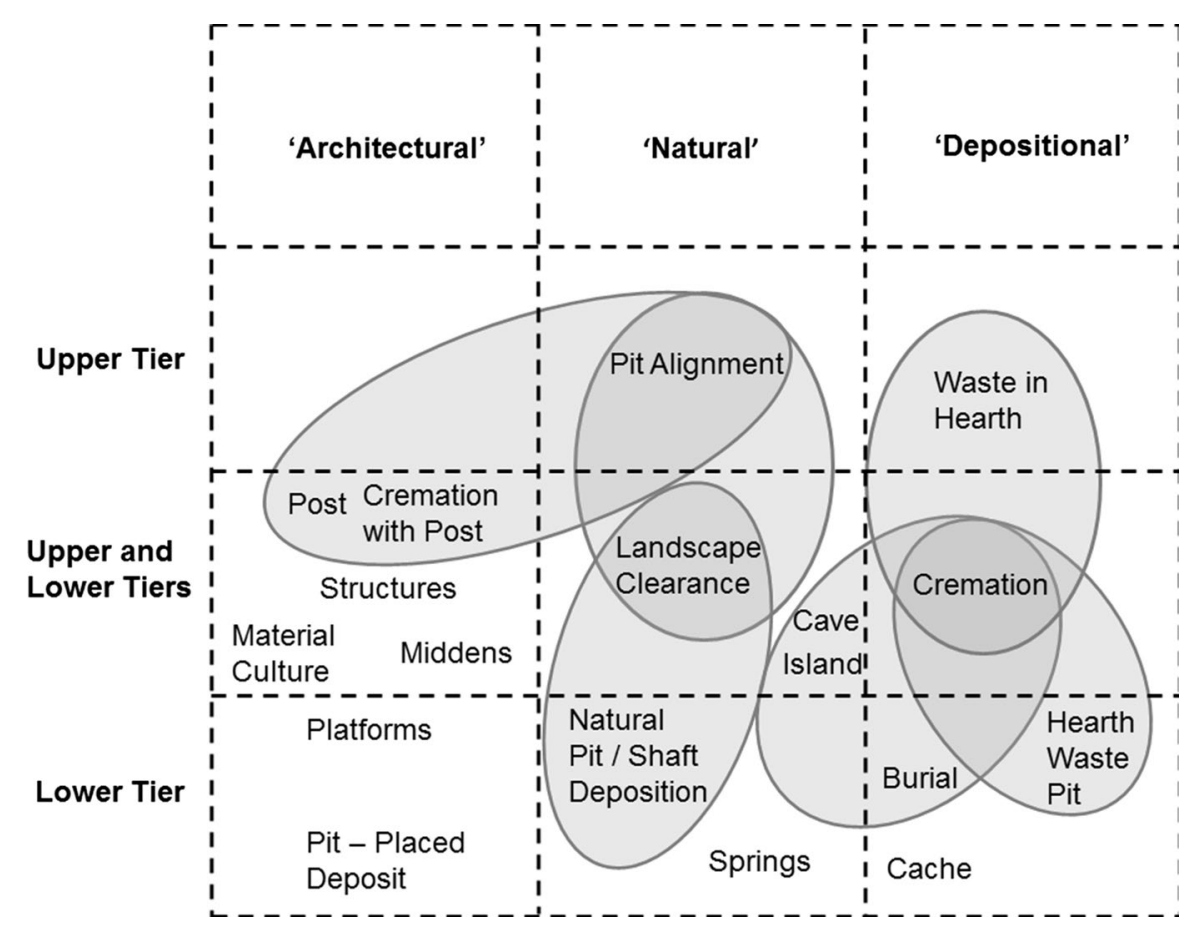

Fig. 5 Provisional structure of Irish and British Mesolithic material evidence for ritual, organised into three-tiered cosmology

repeated desire to make marginal places central, whilst physically fixing and/or changing forms of matter.

Our intention has been to present a variety of evidence for material expressions of ritual in Mesolithic narratives. Descriptions of the Mesolithic have historically prioritised economic activity. Whilst this is essential to understanding past lives, such interpretations have overlooked the social mechanics and spiritual glue which taught successive generations the right way to treat the world around them. This is expressed through seemingly mundane bodies of material remains which, beyond a quest for continued physical prosperity, represent enduring traditions of ritual practice.

Acknowledgements We would like to thank Chantal Conneller and Graeme Warren for inviting us to speak in their TAG Manchester session and for sharing many a conversation about all things ritual. We further thank Nicky Milner (POSTGLACIAL Project), Tracy Collins (Aegis Ltd.) and the Discovery Programme (Ireland) for permission to use their images. Thank you to the anonymous reviewers whose comments greatly improved this paper.

Open Access This article is distributed under the terms of the Creative Commons Attribution 4.0 International License (http://creativecommons.org/licenses/by/4.0/), which permits unrestricted use, distribution, and reproduction in any medium, provided you give appropriate credit to the original author(s) and the source, provide a link to the Creative Commons license, and indicate if changes were made. 


\section{References}

Allen, M., \& Gardiner, J. (2002). A sense of time: Cultural markers in the Mesolithic of southern England? In B. David \& M. Wilson (Eds.), Inscribed landscapes: Marking and making place (pp. 139153). Honolulu: University of Hawaii Press.

Bamforth, M., Taylor, M., Taylor, B., Robson, H. K., Radini, A., \& Milner, N. (2018). Wooden structures. In N. Milner, C. Conneller, \& B. Taylor (Eds.), Star Carr. Volume 1: A persistent place in a changing world (pp. 69-121). York: White Rose University Press.

Blinkhorn, E. (2012). The Mesolithic and the planning process in England. Ph.D. Thesis, University of York.

Bradley, J. (1991). Excavations at Moynagh Lough, Co., Meath. Journal of the Royal Society of Antiquaries of Ireland, 121, 5-26.

Brooks, I. (2007). The flints. In P. Davenport, C. Poole, \& D. Jordan (Eds.), Archaeology in Bath: Excavations at the New Royal Baths (the Spa) and Bellott's Hospital 1998-1999 (pp. 145-149). Oxford: Oxford Archaeology.

Brown, F. (2011). Stainton West (Parcel 27) CNDR, Cumbria: Post-excavation assessment. Oxford Archaeology North, 2011-12/1211.

Brück, J. (1999). Ritual and rationality: Some problems of interpretation in European archaeology. European Journal of Archaeology, 2(3), 313-344.

Brunning, R., \& Firth, H. (2012). An early Mesolithic cemetery at Greylake, Somerset, UK. Mesolithic Miscellany, 22(1), 19-21.

Burrow, S. (2010). Bryn Celli Ddu passage tomb, Anglesey: Alignment, construction, date and ritual. Proceedings of the Prehistoric Society, 76, 249-270.

Chapman, A. (2003). The Hain: Selk'nam initiation ceremony. Santiago: Zagier \& Urruty.

Chatterton, R. (2006). Ritual. In C. Conneller \& G. Warren (Eds.), Mesolithic Britain and Ireland: New approaches (pp. 101-120). Stroud: Tempus.

Clark, J., \& Rankine, W. (1939). Excavations at Farnham, Surrey (1937-1938): The Horsham culture and the question of Mesolithic dwellings. Proceedings of the Prehistoric Society, 5, 61-118.

Cleal, R., Walker, K., \& Montague, R. (1995). Stonehenge in its landscape: The twentieth century excavations. London: English Heritage.

Coles, J. (1971). The early settlement of Scotland: Excavations at Morton, Fife. Proceedings of the Prehistoric Society, 37, 284-366.

Collins, T. (2009). Hermitage, Ireland: Life and death on the western edge of Europe. In S. McCartan, R. Schulting, G. Warren, \& P. Woodman (Eds.), Mesolithic horizons: Papers presented at the seventh international conference on the Mesolithic in Europe, Belfast 2005 (pp. 876-879). Oxford: Oxbow.

Conneller, C. (2006). Death. In C. Conneller \& G. Warren (Eds.), Mesolithic Britain and Ireland: New approaches (pp. 139-164). Stroud: Tempus.

Conneller, C. (2011). The Mesolithic. In T. Insoll (Ed.), The Oxford handbook of the archaeology of ritual and religion (pp. 131-153). Oxford: Oxford University Press.

Conneller, C., Little, A., \& Birchenall, J. (2018). Making space through stone. In N. Milner, C. Conneller, \& B. Taylor (Eds.), Star Carr. Volume 1: A persistent place in a changing world (pp. 157-221). York: White Rose University Press.

Conneller, C., \& Schadla-Hall, T. (2003). Beyond Star Carr: The Vale of Pickering in the tenth millennium BP. Proceedings of the Prehistoric Society, 69, 85-105.

Davies, R. (2012). The nature of Mesolithic activity at selected spring sites in South West England. Ph.D. Thesis. University of Worcester.

Davies, P., \& Griffiths, H. (2005). Molluscan and ostracod biostratigraphy of Holocene tufa in the Test valley at Bossington, Hampshire, UK. The Holocene, 15(1), 97-100.

Davies, P., \& Lewis, J. (2005). A late Mesolithic/Early Neolithic site at Langley's Lane, near Midsomer Norton, Somerset. Past, 49, 7-8.

Driscoll, K. (2006). The early prehistory in the west of Ireland: Investigations into the social archaeology of the Mesolithic, west of the Shannon, Ireland. Mlitt. Thesis, National University of Ireland.

Dunlop, C. (2010). The A6 Toome bypass, Co. Antrim: Archaeological excavation report. Belfast: Northern Archaeological Consultancy, AE/02/059.

Elliott, B. (2012). Antlerworking practices in Mesolithic Britain. Ph.D. thesis, University of York.

Faegre, T. (1979). Architecture of the nomads. London: John Murray. 
Finlay, N. (2003). Cache and carry: Defining moments in the Irish Later Mesolithic. In L. Bevan \& J. Moore (Eds.), Peopling the Mesolithic in a northern environment (pp. 87-94). Oxford: British Archaeological Reports.

Finlay, N. (2004). E-scapes and E-motion: Other ways of writing the Mesolithic. Before Farming, 2004(1), 1-9.

Fredengren, C. (2009). Lake platforms at Lough Kinale: Memory, reach and place. A discovery programme project in the Irish Midlands. In S. McCartan, R. Schulting, G. Warren, \& P. Woodman (Eds.), Mesolithic horizons: Papers presented at the seventh international conference on the Mesolithic in Europe, Belfast (pp. 882-887). Oxford: Oxbow.

Gaffney, V., Fitch, S., Ramsey, E., Yorston, R., Ch'ng, E., Baldwin, E., et al. (2013). Time and a place: A luni-solar 'time-reckoner' from 8th millennium BC Scotland. Internet Archaeology. https://doi. org/10.11141/ia.34.1.

Gilmour, N., \& Loe, L. (2015). A Mesolithic cremation-related deposit from Langford, Essex, England: A first for the British Mesolithic. Mesolithic Miscellany, 23(2), 55-57.

Green, M. (2000). A landscape revealed: 10,000 years on a chalkland farm. Stroud: Tempus.

Hallgren, F., \& Fornander, E. (2016). Skulls on stakes and skulls in water: Mesolithic mortuary rituals at Kanaljorden, Motala, Sweden 7000 BP. In J. M. Grönberg, B. Gramsch, L. Larsson, J. Orschiedt, \& H. Meller (Eds.), Mesolithic burials: Rites, symbols and social organisation of early postglacial communities. Tagungen des Landesmuseums für Vorgeschichte Halle 13/11 (pp. 161-174). Halle: Landesmuseum für Vorgeschichte.

Hammond, S. (2005). Pipeline route: Mercers Quarry, Merstham to North Park Farm Quarry, Godstone, Surrey. An archaeological evaluation, 05/29. Reading: Thames Valley Archaeological Services.

Ingold, T. (1996). Social relations, human ecology, and the evolution of culture: An exploration of concepts and definitions. In A. Lock \& C. Peters (Eds.), Handbook of human symbolic evolution (pp. 178-203). Oxford: Clarendon Press.

Jacques, D., \& Phillips, T. (2014). Mesolithic settlement near Stonehenge: Excavations at Blick Mead, Vespasian's Camp, Amesbury. Wiltshire Archaeological and Natural History Magazine, 107, 7-27.

Jordan, P. (2003a). Peopling the Mesolithic: Insights from ethnographies of landscape and material culture. In L. Bevan \& J. Moore (Eds.), Peopling the Mesolithic in a northern environment (pp. 27-34). Oxford: Archaeopress.

Jordan, P. (2003b). Investigating post-glacial hunter-gatherer landscape enculturation: Ethnographic analogy and interpretative methodologies. In L. Larsson, H. Kindgren, K. Knutsson, D. Loeffler, \& A. Akerlund (Eds.), Mesolithic on the move: Papers presented at the sixth international conference on the Mesolithic in Europe, Stockholm 2000 (pp. 128-138). Oxford: Oxbow.

Jordan, P. (2003c). Material culture and sacred landscape: The anthropology of the Siberian Khanty. Oxford: Alta Mira Press.

Lawton-Matthews, E. (2012). In the pits: Exploring pits, caching and deposition in the Irish Mesolithic. MA thesis, University College Dublin.

Lewis, J., Leivers, M., Brown, L., Smith, A., Cramp, K., Mepham, L., et al. (2010). Landscape evolution in the Middle Thames Valley: Heathrow Terminal 5 excavations, Volume 2. Framework Archaeology Monograph no. 3. Oxford and Salisbury: Framework Archaeology.

Lewis, J., \& Pine, J. (2008). Pendell Farm, Bletchingley, Surrey: An archaeological evaluation, Phase 1, 08/13. Reading: Thames Valley Archaeological Services.

Little, A. (2005). Reconstructing the social topography of an Irish Mesolithic lakescape. In H. Cobb, F. Coward, L. Grimshaw, \& S. Price (Eds.), Investigating prehistoric identities: Case studies from Palaeolithic and Mesolithic Europe (pp. 79-94). Oxford: British Archaeological Reports.

Little, A. (2010). Tasks, temporalities and textures: Reconstructing the social topography of an Irish Mesolithic lakescape. Ph.D. thesis, University College Dublin.

Little, A., Elliott, B., Conneller, C., Pomstra, D., Evans, A., Fitton, L., et al. (2016). Technological analysis of the world's earliest shamanic costume: A multi-scalar, experimental study of a red deer headdress from the Early Holocene site of Star Carr, North Yorkshire, UK. PLoS ONE, 11(4), e0152136.

Little, A., van Gijn, A., Collins, T., Cooney, G., Elliott, B., Gilhooly, B., et al. (2017). Stone dead: Uncovering Early Mesolithic mortuary rites, Hermitage, Ireland. Cambridge Archaeological Journal, 27(2), 223-243.

Mandelbaum, D. (1979). The Plains Cree: An ethnographic, historical and comparative study. Regina: University of Regina.

McKinley, J., Riddler, I., \& Trevarthen, M. (2006). The prehistoric, Roman and Anglo-Saxon funerary landscape at Saltwood Tunnel, Kent. Oxford: Oxford Wessex Archaeology Joint Venture (London and Continental Railways). https://doi.org/10.5284/1008823. 
Meiklejohn, C., \& Woodman, P. (2012). Radiocarbon dating of Mesolithic human remains in Ireland. Mesolithic Miscellany, 22(1), 22-41.

Mellars, P. (2009). Moonshine over Star Carr: Post-processualism, Mesolithic myths and archaeological realities. Antiquity, 83, 502-517.

Milner, N., Bamforth, M., Beale, G., Carty, J., Konstantinos, C., Croft, S., et al. (2016). A unique engraved shale pendant from the site of Star Carr: The oldest Mesolithic art in Britain. Internet Archaeology, 40.

Mithen, S. J. (2000). Hunter-gatherer landscape archaeology: The Southern Hebrides Mesolithic project 1988-1995. Cambridge: McDonald Institute for Archaeological Research.

Mossop, M. (2009). Lakeside developments in County Meath, Ireland: A Late Mesolithic fishing platform and possible mooring at Clowanstown 1. In S. McCartan, R. Schulting, G. Warren, \& P. Woodman (Eds.), Mesolithic horizons: Papers presented at the seventh international conference on the Mesolithic in Europe, Belfast (pp. 895-899). Oxford: Oxbow.

Murray, H., Murray, J., \& Fraser, S. M. (2009). A tale of the unknown unknowns: A Mesolithic pit alignment and a Neolithic timber hall at Warren Field, Crathes, Aberdeenshire. Oxford: Oxbow.

Needham, A., Croft, S., Kröger, R., Robson, H. K., Rowley, C. C. A., Taylor, B., et al. (2018a). The application of micro-Raman for the analysis of ochre artefacts from Mesolithic palaeo-lake Flixton. Journal of Archaeological Science: Reports, 17, 650-656.

Needham, A., Little, A., Conneller, C., Pomstra, D., Croft, S., \& Milner, N. (2018b). Beads and pendant. In N. Milner \& C. C. T. Barry (Eds.), Star Carr. Volume 2: Studies in technology, subsistence and environment (pp. 463-477). York: White Rose University Press.

Newell, R. (1981). Mesolithic dwelling structures: Fact and fantasy. In B. Gramsch (Ed.) Mesolithikum in Europa. 2. Internationales symposium Potsdam, 3. bis 8. April 1978. Veröffentlichungen des Museums für Ur- und Frühgeschichte Potsdam, 14/15 (pp. 235-284). Berlin: Deutscher Verlag der Wissenschaften.

O'Malley, M., \& Jacobi, R. M. (1978). The excavation of a Mesolithic occupation site at Broom Hill. Braishfield, Hampshire, Rescue Archaeology in Hampshire, 4, 16-39.

OED Online (2018). 'ritual, adj. and n.'. Oxford University Press. www.oed.com/view/Entry/166369. Accessed 3 January 2018.

Ryan, M. (1980). An Early Mesolithic site in the Irish Midlands. Antiquity, 54(210), 46-47.

ScARF (2012). Scottish archaeological research framework: Palaeolithic and Mesolithic. http://www. scottishheritagehub.com/content/palaeolithic-mesolithic-panel-report. Accessed 13 April 2016.

Tanner, A. (1979). Bringing home animals: Religious ideology and mode of production of the Mistissini Cree Hunters. St. John's: Memorial University of Newfoundland.

Taylor, B., Conneller, C., Milner, N., Elliott, B., Little, A., Knight, B., et al. (2018a). Human lifeways. In N. Milner, C. Conneller, \& B. Taylor (Eds.), Star Carr. Volume 1: A persistent place in a changing world (pp. 245-272). York: White Rose University Press.

Taylor, B., Milner, N., \& Conneller, C. (2018b). Dryland structures. In N. Milner, C. Conneller, \& B. Taylor (Eds.), Star Carr. Volume 1: A persistent place in a changing world (pp. 57-68). York: White Rose University Press.

van Gijn, A. (2010). Flint in focus: Lithic biographies in the Neolithic and Bronze Age. Leiden: Sidestone Press.

Van Wijngaarden-Bakker, L. (1989). Faunal remains and the Irish Mesolithic. In C. Bonsall (Ed.), The Mesolithic in Europe: Papers presented at the third international symposium, Edinburgh 1985 (pp. 125-133). Edinburgh: John Donald.

Walker, M. (2015). All the colours of the rainbow: An experimental investigation into the reconstruction of the colourscape of Mesolithic Star Carr. MA thesis, The University of Manchester.

Warren, G. (2007). Mesolithic myths. In V. Cummings \& A. Whittle (Eds.), Going over: The MesolithicNeolithic transition in north-west Europe (pp. 311-328). London: British Academy.

Woodman, P. (1985). Excavations at Mount Sandel, 1973-77. Belfast: Her Majesty's Stationery Office.

Woodman, P. (2015). Ireland's first settlers: Time and the Mesolithic. Oxford: Oxbow Books.

Woodman, P., Anderson, E., \& Finlay, N. (1999). Excavations at Ferriter's Cove 1983-1995: Last foragers, first farmers in the Dingle Peninsula. Dublin: Wordwell.

Zvelebil, M. (2008). Innovating hunter-gatherers: The Mesolithic in the Baltic. In G. Bailey \& P. Spikins (Eds.), Mesolithic Europe (pp. 18-59). Cambridge: Cambridge University Press. 